\title{
The Role of Interferon Regulatory Factor-1 and Interferon Regulatory Factor-2 in IFN- $\gamma$ Growth Inhibition of Human Breast Carcinoma Cell Lines
}

\author{
JOHN H. YIM, ${ }^{1}$ SIMON H. RO, ${ }^{2}$ JENNIFER K. LOWNEY, ${ }^{2}$ SUSAN J. WU, ${ }^{2}$ JUDITH CONNETT, ${ }^{3}$ \\ and GERARD M. DOHERTY ${ }^{3}$
}

\begin{abstract}
Interferon (IFN) regulatory factor-1 (IRF-1) and IRF-2 play opposing roles in the regulation of many IFN$\gamma$-inducible genes. To investigate the signal transduction pathway in response to IFN- $\gamma$ in light of differences in growth effects, we selected four human breast carcinoma cell lines based on a spectrum of growth inhibition by IFN- $\gamma$. MDA468 growth was markedly inhibited by IFN- $\gamma$, and it showed substantial induction of IRF-1 mRNA but little IRF-2 induction. SKBR3 showed little growth inhibition and little induction of IRF-1 mRNA but significant induction of IRF-2 mRNA. HS578T and MDA436 growth inhibition and IRF-1/IRF-2 induction were intermediate. All four cell lines showed intact receptor at the cell surface and Stat1 translocation to the nucleus by immunostaining. By EMSA, there were marked differences in the induced ratio of IRF-1 and IRF-2 binding activity between the cell lines that correlated with growth inhibition. Finally, antisense oligonucleotides specific for IRF-1 attenuated IFN- $\gamma$ growth inhibition in MDA436 and MDA468, confirming the direct role of IRF-1 in IFN- $\gamma$ growth inhibition. Induction of IRF-1 causes growth inhibition in human breast cancer cell lines, and induction of IRF-2 can oppose this. The relative induction of IRF-1 to IRF-2 is a critical control point in IFN- $\gamma$ response.
\end{abstract}

\section{INTRODUCTION}

I NTERFERON (IFN) REGULATORY FACTORS 1 AND 2 (IRF-1 and IRF-2) are nuclear transcription factors that bind the same DNA sequence in the promoter regions of genes known to be induced by IFNs. However, IRF-1 is a transcriptional activator to upregulate gene expression, and IRF-2 generally appears to downregulate, or block upregulation, of the same genes. Although viruses, dsRNA, and type I IFNs were initially found to induce IRF-1 production, IFN- $\gamma$ has been found to be the most reliable and powerful inducer of IRF-1. ${ }^{(1-3)}$ IRF-1 mediates several IFN- $\gamma$ effects on cells, including (1) inducible nitric oxide synthase (iNOS) expression by macrophages, ${ }^{(4,5)}(2)$ guanylate binding protein (gbp) expression, (6) (3) MHC class I expression, ${ }^{(7-9)}$ (4) MHC class II expression, ${ }^{(10-12)}$ and (5) IFN- $\alpha / \beta$ expression. ${ }^{(9,13,14)}$ More recently, IRF-1 has also been implicated in the upregulation of Fas ligand in T cells ${ }^{(15)}$ and cyclooxygenase-2(COX-2) in macrophages. ${ }^{(16)} \mathrm{IRF}-2$ is induced later than IRF-1 and appears to have greater protein stability. ${ }^{(17)}$
Therefore, IRF-2 may play a role in feedback inhibition of IFN$\gamma$ effects mediated by IRF-1, and the ratio of IRF-1/IRF- 2 may be critical for determining the cellular response to IFN- $\gamma$.

The two IRF proteins also appear to have opposing roles in the regulation of cell growth and tumorigenicity. NIH3T3 cells overexpressing the IRF-2 gene became transformed and were more tumorigenic in nude mice, implicating IRF-2 as a potential oncoprotein. ${ }^{(18)}$ In contrast, IRF-1 overexpression in the IRF-2-transformed cells reversed this phenotype, implicating IRF-1 as a tumor suppressor. ${ }^{(18)}$ Similarly, embryonic fibroblasts from knockout mice lacking IRF-1 were transformed by introduction of the c-Ha-ras oncogene, whereas normal cells were not. This was reversed by IRF-1 gene transfection. ${ }^{(19)}$ Previously, we demonstrated that IRF-1 overexpression in MCA 101 cells can suppress the malignant phenotype and enhance immunogenicity in syngeneic mice. ${ }^{(12)}$ In addition, the chromosomal region containing the IRF-1 gene is deleted in some patients with leukemia or myelodysplastic syndromes, ${ }^{(20)}$ gastric adenocarcinomas, ${ }^{(21)}$ and esophageal carcinomas, ${ }^{(22)}$ sug-

\footnotetext{
${ }^{1}$ Department of Surgery, University of Pittsburgh School of Medicine, Pittsburgh, PA 15261.

${ }^{2}$ Laboratory of Cytokine and Tumor Biology, Department of Surgery, Washington University School of Medicine, St. Louis, MO 63110-1093.

${ }^{3}$ Department of Surgery, University of Michigan School of Medicine, Ann Arbor, MI 48109.
} 
gesting a possible tumor suppressor role for IRF-1 in human cancer.

Data from our laboratory are consistent with the involvement of this pathway in the development and progression of human cancer. We showed progressive loss of IRF-1 expression with more advanced melanoma, as judged by morphology, thickness, and stage. ${ }^{(23)}$ Thicker lesions and nodular lesions are more likely to have lost IRF-1 expression, compared with more favorable lesions. Human breast cancers showed frequent loss of IRF-1 and gain of IRF-2 expression with in situ and invasive lesions, which also correlates with the likelihood of axillary lymph node involvement.(24) This was substantially different from the nearly universal expression of IRF-1 and rare expression of IRF-2 in normal breast tissue.

To evaluate the role of this pathway in endogenous control of tumor growth, we have used murine models. With RT-PCR, we have shown that IRF-1 and IRF-2 expression patterns are consistent with opposing roles in IFN- $\gamma$ growth inhibition in murine tumor cells in vitro, with IRF-1 correlating with inhibition of growth and IRF-2 opposing inhibition. ${ }^{(25)}$ In particular, the growth of the mouse melanoma cell line B16-F10 was markedly inhibited by IFN- $\gamma$, and the cell line showed almost no IRF-2 induction by RT-PCR. We have also demonstrated that IRF-2 overexpression in B16-F10 cells can increase tumorigenicity in syngeneic mice by both increased rate of cell growth and increased resistance to IFN- $\gamma .^{(26)}$

Although we have significant data to support the role of IRF1 and IRF-2 in IFN- $\gamma$-mediated growth inhibition in the mouse model, there have been very few studies assessing the role of IRF-1 and IRF-2 in IFN growth inhibition in human cancer cells. In fact, two studies have been unable to find a correlation of IRF-1 and IRF-2 with type I IFN response or lack of response in human cancer cells, ${ }^{(27,28)}$ although no study has been performed to date for IFN- $\gamma$. IFN- $\gamma$ has significant antitumor activity and has been shown to play an important role in the antitumor activity of other cytokines, including tumor necrosis factor- $\alpha$ (TNF- $\alpha$ ) and interleukin-12 (IL-12). We and others have shown that endogenous IFN- $\gamma$ appears to play a role in suppression of some tumors. Conversely, how tumors respond to IFN- $\gamma$ may play a critical role in tumor progression. In this study, we analyzed four human breast carcinoma cell lines with a spectrum of growth inhibitory responses to IFN- $\gamma$ for IRF-1 and IRF-2 induction at the level of mRNA and protein binding activity using RT-PCR and electrophoretic mobility shift assay (EMSA). We then evaluated the role of IRF-1 in mediating the IFN- $\gamma$ growth effects with antisense techniques.

\section{MATERIALS AND METHODS}

\section{Human breast cancer cell lines}

The human breast cell lines BT20 (BT-20), SKBR3 (SK-BR3), HS578T, MDA436 (MDA-MB-436), MDA468 (MDA-MB468), ZR75-1 (ZR-75-1), and T47D (T-47D) were obtained from American Type Culture Collection (Rockville, MD). T47D and HS578T were cultured in vitro in DMEM medium supplemented with $10 \%$ fetal bovine serum (FBS), L-glutamine, penicillin/streptomycin, and gentamicin (DMEM-CM). BT20, MDA468, and MDA436 were cultured in DMEM-CM and
Ham's F12 medium mixed in a 1:1 ratio. SKBR3 and ZR75-1 were cultured in RPMI 1640 supplemented with $10 \%$ FBS, Lglutamine, penicillin/streptomycin, and gentamicin. All cells were incubated at $37^{\circ} \mathrm{C}$ at $5 \% \mathrm{CO}_{2}$.

\section{Assay of cell growth in vitro}

Cells were plated in $200 \mu \mathrm{l}$ of appropriate medium in the inner 60 wells of 96 -well plates at $2 \times 10^{3}$ cells/well, either in the presence or absence of $100 \mathrm{U} / \mathrm{ml}$ recombinant human IFN$\gamma$ (PharMingen, San Diego, CA). MTT ( $5 \mathrm{mg} / \mathrm{ml}$ ) (Sigma, St. Louis, MO) was added at $20 \mu \mathrm{l} /$ well to triplicate wells daily. After $24 \mathrm{~h}$ incubation with MTT, the medium was removed from the triplicate wells. The formazan crystals were allowed to air dry before being dissolved in mineral oil (50 $\mu \mathrm{l} /$ well) (Schnucks Markets, Bridgeton, MO). Absorbance was measured at $595 \mathrm{~nm}$ on a microplate reader (Bio-Rad, Richmond, CA).

\section{Detection of $m R N A$}

Subconfluent cells were trypsinized and washed in phosphatebuffered saline (PBS) and frozen at $-70^{\circ} \mathrm{C}$. mRNA was isolated from cells using detergent lysis and oligo dT spun columns (Micro-FastTrack $^{\mathrm{TM}}$ kit, Invitrogen, San Diego, CA). cDNA was prepared by RT reaction of identical amounts of isolated mRNA (RT-PCR kit, Stratagene, La Jolla, CA). Equivalent amounts of cDNA were amplified by PCR for assessment of human IRF mRNA expression using the primers 5'-AGATCCCATGGAAGCATGCTG-3' (sense) and 5'-CCTGGAACTGTGTAGCTGC-3' (antisense) for human IRF-1 and 5'-CAAGTGGCTTAACAAGG-3' (sense) and 5'-GGACCGCATACTCAGGAG-3' (antisense) for human IRF-2. PCR buffer (10 mM KCl, $10 \mathrm{mM}\left(\mathrm{NH}_{4}\right)_{2} \mathrm{SO}_{4}, 20 \mathrm{mM}$ Tris- $\mathrm{HCl}, \mathrm{pH} 8.8,2 \mathrm{mM} \mathrm{MgSO}_{4}$, $0.1 \%$ Triton X-100 [New England BioLabs, Beverly, MA]), dNTPs (GIBCO-BRL, Gaithersburg, MD), primers, and VentR polymerase (New England BioLabs) were added, followed by 30 cycles at $94^{\circ} \mathrm{C}$ for $50 \mathrm{sec}, 55^{\circ} \mathrm{C}$ for $50 \mathrm{sec}, 72^{\circ} \mathrm{C}$ for $60 \mathrm{sec}$. Amplified product $(8 \mu \mathrm{l})$ was separated by electrophoresis on $0.7 \%$ agarose minigels and stained with ethidium bromide. Although no quantitative measurements of mRNA production can be made from this method of RT-PCR, qualitative assessments of differences in degree of production can be made from obvious differences in band intensity, as identical amounts of cDNA were used for PCR and identical amounts of PCR product were run on the gels. No comparisons can be made between products from different primers. The primers for cyclophilin, 5'-CGTGTGAAGTCACCACCCT-3' (sense) and 5'-ATGGTCAACCCCACCGTGTT-3' (antisense), were generous gifts from Dr. Jeffrey Moley (Washington University, St. Louis, MO) and were used in all cases as an internal control.

\section{Flow cytometry}

Subconfluent cells were trypsinized, washed, and directly treated with FITC-labeled antihuman IFN- $\gamma$ receptor monoclonal antibody mAb (Serotec, Raleigh, NC). FITC-labeled irrelevant $\mathrm{Ab}$ was used as a control. All incubations and subsequent washes were performed in PBS containing 3\% neonatal calf serum and $0.1 \%$ sodium azide. Cells were analyzed with a FACScan flow cytometer (Becton Dickinson, Mountain View, CA). 


\section{Stat1 immunohistochemistry}

Cells were grown on chamber slides (Nunc, Inc., Naperville, IL) in appropriate medium for $24 \mathrm{~h}$ in a $37^{\circ} \mathrm{C}$ sterile incubator. After coincubation with $100 \mathrm{U} / \mathrm{ml} \mathrm{IFN}-\gamma$ or control for $1 \mathrm{~h}$, the cells were briefly washed with PBS and subsequently fixed with


Permeabilization was performed with $1 \%$ Triton-X 100 for 2 min, followed by washes with $0.1 \%$ Tween $20 /$ PBS. Nonspecific binding of the secondary antibody was blocked with $2 \%$ bovine serum albumin (BSA) in PBS for $1 \mathrm{~h}$ at ambient temperature. The Stat1 primary antibody was a generous gift from Chris Schindler (Columbia University, New York, NY). It is a rabbit polyclonal antibody raised against a GST fusion protein encoding the last 36 amino acids of human Stat1. This polyclonal antibody at 1:500 titer was incubated overnight at $4^{\circ} \mathrm{C}$ in a rotating, humidified chamber. After rinsing with PBS, a secondary antibody conjugated to $\mathrm{Cy} 3$ (goat antirabbit-Cy3, $\mathrm{H}+\mathrm{L}$ ) (Jackson Immunology, West Grove, PA) was incubated for $15 \mathrm{~min}$ at ambient temperature. Excess secondary antibody was rinsed off, and a slow fade mounting medium, DABCO in glycerol (Sigma), was covered with glass coverslips. The slides were analyzed with a confocal laser scanning microscope equipped with an argon/krypton ion laser and were sectioned at $0.5-\mu \mathrm{m}$ intervals in the $512 \times 512$ pixel format. To determine background nonspecific staining, a negative control was performed without primary antibody incubation. No binding was observed.

\section{EMSA}

Whole cell extracts were obtained from trypsinized subconfluent monolayers of cells and prepared as described by Harada et al. ${ }^{(13)}$ Briefly, pelleted cells were suspended in $4 \times$ vol lysis buffer (20 mM HEPES, pH 7.9, $50 \mathrm{mM} \mathrm{NaCl}, 10 \mathrm{mM}$ EDTA, $2 \mathrm{mM}$ EGTA, $10 \mathrm{mM}$ molybdate, $10 \mathrm{mM}$ vanadate, $100 \mathrm{mM}$ $\mathrm{NaF}, 0.1 \% \mathrm{NP} 40,0.5 \mathrm{mM}$ PMSF, $100 \mu \mathrm{g} / \mathrm{ml}$ leupeptin), sonicated for $2 \mathrm{~min}$, and centrifuged at $10,000 \mathrm{rpm}$ for $10 \mathrm{~min}$. The supernatant was used as cell extract. Extracts $(15 \mu \mathrm{g} / \mathrm{sample})$ were mixed with ${ }^{32} \mathrm{P}$-labeled $\mathrm{C} 13$ oligomer $(\sim 1.5 \mathrm{pmol} / \mathrm{sam}-$ ple, 50,000-200,000 cpm/sample; sequence derived from $\mathrm{Fu}$ jita et al. ${ }^{(29)}$ specifically binds IRF-1 and IRF-2), $1 \mu \mathrm{g}$ herring sperm DNA, and $2 \mu \mathrm{g}$ poly $(\mathrm{dI}: \mathrm{dC})$ and incubated at $25^{\circ} \mathrm{C}$ for $60 \mathrm{~min}$ in a final volume of $10 \mu \mathrm{l}$ buffer containing $10 \mathrm{mM}$ Tris- $\mathrm{HCl}, \mathrm{pH}$ 7.5, $50 \mathrm{mM} \mathrm{NaCl}, 1 \mathrm{mM}$ DTT, $1 \mathrm{mM}$ EDTA, and $5 \%$ glycerol. Alternatively, 1.75 pmol unlabeled $\mathrm{C} 13$ was added to each sample for competition experiments. Some extracts were preincubated with $1 \mu \mathrm{l}$ antibody (anti-IRF-1 or anti-IRF2, $1 \mu \mathrm{g} / \mu \mathrm{l}$ ) (Santa Cruz Biotechnology, Inc., Santa Cruz, CA) at $0^{\circ} \mathrm{C}$ for $60 \mathrm{~min}$ before mixing with oligomer. The IRF-1 antibody is an affinity-purified rabbit polyclonal antibody raised against a peptide representing amino acids 306-325 of the carboxyl-terminus. This antiserum is not cross-reactive with IRF2 or IFN-stimulated gene factor $3 \gamma$ (ISGF3 $\gamma$ ). The IRF- 2 antibody is an affinity-purified rabbit polyclonal antibody raised against a peptide corresponding to amino acids 331-348 mapping at the carboxy-terminus and does not cross-react with IRF1 or ISGF3 $\gamma$. Because these antibodies are specific for the carboxy-terminus, they do not interfere with DNA binding and create supershifted complexes forming bands of intensity on autoradiographs correlating with the amount of protein bound to the radiolabeled oligonucleotide probe. The samples were run on preelectrophoresed nondenaturing $4 \%$ polyacrylamide gels and autoradiographed.

\section{Antisense oligonucleotide experiments}

The phosphorothioate antisense oligonucleotide against IRF-1 (IRF-1 AS) was synthesized (Oligos Etc. Inc., Wilsonville, OR) with the sequence 5'-CGAGTGATGGGCATGTTGGC-3' for targeting the translation initiation site in human IRF-1 mRNA. This sequence was obtained from Sato et al. ${ }^{(30)}$ and has been shown to markedly decrease IRF-1 protein levels by immunoblotting and IRF-1 mRNA by RT-PCR. A nonspecific phosphorothioate oligonucleotide with the sequence 5'-TGGATCCGACATGTCAGA-3' (NS, Oligos Etc. Inc.) was used as a control.

Cells in log phase growth at $30 \%-50 \%$ confluency in 96well plates were cultured with IRF-1 AS, NS, or no oligo in varying concentrations in reduced serum medium (Opti-MEM, GIBCO-BRL) at $100 \mu \mathrm{l} /$ well. Four hours later, $100 \mu \mathrm{l} \mathrm{Opti-}$ MEM with identical concentrations of oligonucleotide with or without IFN- $\gamma$ at $200 \mathrm{U} / \mathrm{ml}$ was added in triplicate to give a final concentration of $100 \mathrm{U} / \mathrm{ml}$ IFN- $\gamma$. Four to five days later, MTT was used to assay viable cell number. Alternatively, cells were plated in 6-well plates with oligonucleotide or no oligo at $1 \mathrm{ml} /$ well. Four hours later, $1 \mathrm{ml}$ Opti-MEM with identical concentrations of oligonucleotide with IFN- $\gamma$ at $200 \mathrm{U} / \mathrm{ml}$ was added, and 2 days later, cells were harvested for EMSA.

\section{RESULTS}

Assessment of growth inhibition and IRF-1 and IRF-2 $m R N A$ expression by RT-PCR in seven human breast carcinoma cell lines

We initially performed growth assays and RT-PCR for IRF1 and IRF-2 mRNA expression on seven human breast carcinoma cell lines to define the most heterogeneous group of cell lines in growth inhibitory response to IFN- $\gamma$. We then assessed the possibility of correlation of IRF-1 and IRF-2 expression with the response, understanding the limitations and qualitative nature of RT-PCR (Fig. 1). SKBR3 showed almost no inhibition of growth with $100 \mathrm{U} / \mathrm{ml}$ IFN- $\gamma$ incubation, whereas MDA468 showed tremendous inhibition of growth. BT20, HS578T, ZR75-1, MDA436, and T47D all had an intermediate response to IFN- $\gamma$ in terms of growth inhibition. Growth inhibition was not significantly changed in any cell line, including SKBR3, by an increase to $1000 \mathrm{U} / \mathrm{ml}$ IFN- $\gamma$ (data not shown). The growth inhibition correlated with the assessed IRF-1 mRNA expression by RT-PCR, with SKBR3 showing the least expression of IRF-1 mRNA and MDA468 showing the most. Other cell lines had intermediate levels of IRF-1 mRNA by RTPCR. Furthermore, SKBR3 also showed clearly increased IRF2 mRNA by RT-PCR, whereas all the other cell lines showed barely detectable levels of IRF-2 mRNA.

Correlation of IRF-1 and IRF-2 mRNA expression by $R T-P C R$ with growth inhibitory response to IFN- $\gamma$ in four human breast carcinoma cell lines

In Figure 2, we show the entire pattern of growth inhibition by IFN- $\gamma$ on the four human breast carcinoma cell lines we 


\begin{tabular}{|c|c|c|c|}
\hline Cell Line & $\begin{array}{l}\text { IFN- } \gamma \text { Inhibition of cell growth } \\
(\% \text { inhibition at } 9 \text { days })\end{array}$ & $\begin{array}{l}\text { IRF-1 assessed } \\
\text { by RT-PCR }\end{array}$ & $\begin{array}{l}\text { IRF-2 assessed } \\
\text { by RT-PCR }\end{array}$ \\
\hline SKBR3 & & + & ++ \\
\hline BT20 & & ++ & + \\
\hline HS578T & & ++++ & + \\
\hline ZR75-1 & & +++ & + \\
\hline MDA436 & & +++ & + \\
\hline T47D & & ++++ & + \\
\hline MDA468 & & +++++ & + \\
\hline & $\begin{array}{r}1 \\
60 \\
\end{array}$ & & \\
\hline
\end{tabular}

FIG. 1. Assessment of IFN- $\gamma$ growth inhibition and IRF-1 and IRF-2 mRNA expression by RT-PCR in seven human breast carcinoma cell lines. Each cell line was plated at $2 \times 10^{3}$ cells/well on 96 -well plates in appropriate medium with or without 100 $\mathrm{U} / \mathrm{ml}$ IFN- $\gamma$. MTT was applied to wells daily in triplicate. The medium was aspirated the next day, and at the end of the experiment, tetrazolium crystals dissolved in mineral oil and wells read on a spectrophotometer. The bar graph depicts the percentage inhibition of growth after 9 days of incubation. For RT-PCR, each cell line was plated at $5 \times 10^{5}$ cells/well on 6 -well plates in appropriate medium and allowed to adhere overnight. Cells were treated with $100 \mathrm{U} / \mathrm{ml} \mathrm{IFN}-\gamma$ the next day. After 0.5 , 1,6 , and $24 \mathrm{~h}$ of treatment, cells were trypsinized, mRNA was obtained using spun oligo dT columns, and RT-PCR was performed using specific primers for IRF-1 and IRF-2. The intensity and earliest point of induction correlated with each other and were subjectively assessed to determine the level of expression, which is designated by the number of + signs $(+$ to +++++$)$.

chose for further study, the full time course of induced IRF-1 and IRF-2, and control cyclophilin mRNA expression by RTPCR. MDA468, which clearly showed the greatest inhibition and possibly even a cytotoxic response to IFN- $\gamma$, also showed the earliest and greatest induction of IRF-1 mRNA by RT-PCR. SKBR3, which showed almost no growth inhibition, also showed very little induction of IRF-1 mRNA by RT-PCR and also showed clearly detectable IRF-2 mRNA at $24 \mathrm{~h}$. HS578T and MDA436, which showed intermediate growth inhibition by IFN- $\gamma$, also showed intermediate levels of IRF-1 mRNA.

\section{Assessment of IFN- $\gamma$ receptor presence and Stat1 translocation}

SKBR3 resistance to growth inhibition and poor expression of IRF-1 by RT-PCR in response to IFN- $\gamma$ could be explained
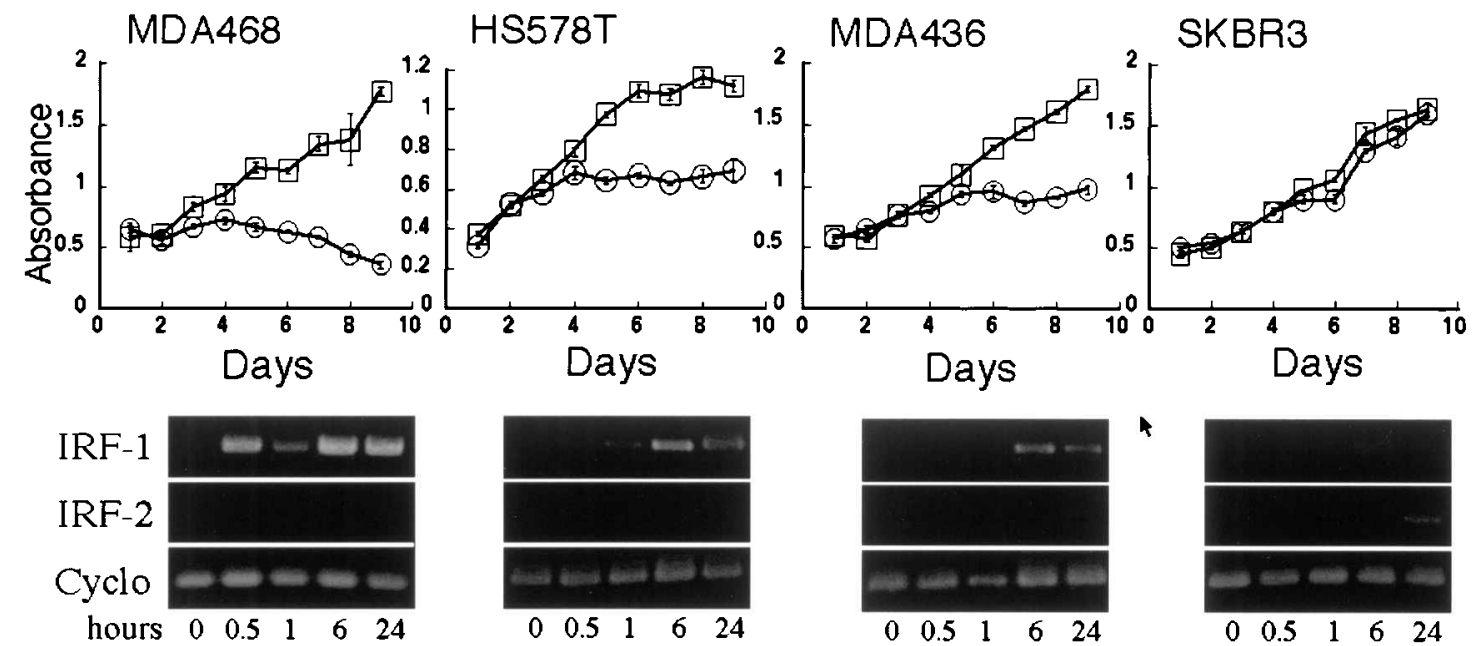

FIG. 2. IFN- $\gamma$ growth inhibition and IRF-1 and IRF-2 mRNA expression by RT-PCR in four human breast carcinoma cell lines. Cells were assessed for growth and IRF-1 and IRF-2 mRNA expression in response to IFN- $\gamma$ as detailed in the Figure 1 legend. (Top) Entire pattern of growth inhibition in four cell lines by the growth assay detailed in the Figure 1 legend. (Bottom) Full time course of IRF-1 and IRF-2 and cyclophilin (Cyclo) mRNA expression by RT-PCR performed as detailed in the Figure 1 legend. 
by low levels or absence of IFN- $\gamma$ receptor. However, SKBR3 clearly has significant levels of IFN- $\gamma$ receptor on the cell surface, as assessed by flow cytometry (data not shown). Alternatively, SKBR3 resistance to growth inhibition and low IRF-1 expression could also be due to signal transduction defects proximal to IRF-1. In particular, Stat 1 translocation to the nucleus is a critical event in IFN- $\gamma$ signal transduction. ${ }^{(31,32)}$ In fact, defects at the level of Stat1 have been reported in IFN-resistant human melanoma cells. ${ }^{(33)}$ However, each cell line, including MDA468 and SKBR3, showed translocation of Stat1 to the nucleus after stimulation with $100 \mathrm{U} / \mathrm{ml} \mathrm{IFN}-\gamma$ for $1 \mathrm{~h}$, as demonstrated by immunohistochemistry, with clear nuclei in the unstimulated cells changing to nuclear staining in the presence of IFN- $\gamma$ (Fig. 3).

\section{Expression of IRF proteins in response to IFN- $\gamma$ by EMSA}

We performed EMSA to analyze IRF-1 and IRF-2 induction by IFN- $\gamma$ in the four human breast carcinoma cell lines for several reasons: (1) EMSA measures protein binding to a specific consensus sequence and thus identifies not only protein but also functionality or activity to the extent of DNA binding. (2)
EMSA with IRF-1 or IRF-2 antibody and densitometry allows for relative quantitation between different cell lines and different treatments and for comparison between IRF-1 and IRF-2 protein expression. This has been an accepted method of analysis of EMSA results. ${ }^{(14,18)}$ (3) EMSA does not suffer from certain technical limitations as does RT-PCR, such as variable results with different primers. The radiolabeled $\mathrm{C} 13$ oligomer binds both IRF-1 and IRF-2 but binds no other known DNAbinding proteins. Our initial studies were performed without antibodies to evaluate overall IRF induction by IFN- $\gamma$ in the four human breast carcinoma cell lines (Fig. 4). There were low levels of baseline IRF seen in all four cell lines that were markedly increased by incubation with $100 \mathrm{U} / \mathrm{ml}$ and $250 \mathrm{U} / \mathrm{ml}$ IFN- $\gamma$ for 2 days. Clearly, IFN- $\gamma$ signal transduction is intact down to this level. However, there was no correlation between this response and the level of growth inhibition. SKBR3, which showed almost no growth inhibition, has a significant response in IRF production, whereas HS578T has the least IRF response (Fig. 3).

When we used antibodies to distinguish IRF-1 and IRF-2, we found marked differences in the ratio of IRF-1/IRF-2 after IFN- $\gamma$ stimulation, and this ratio correlated with IFN- $\gamma$ inhibition of growth (Fig. 5 compared with Fig. 2). These relation-
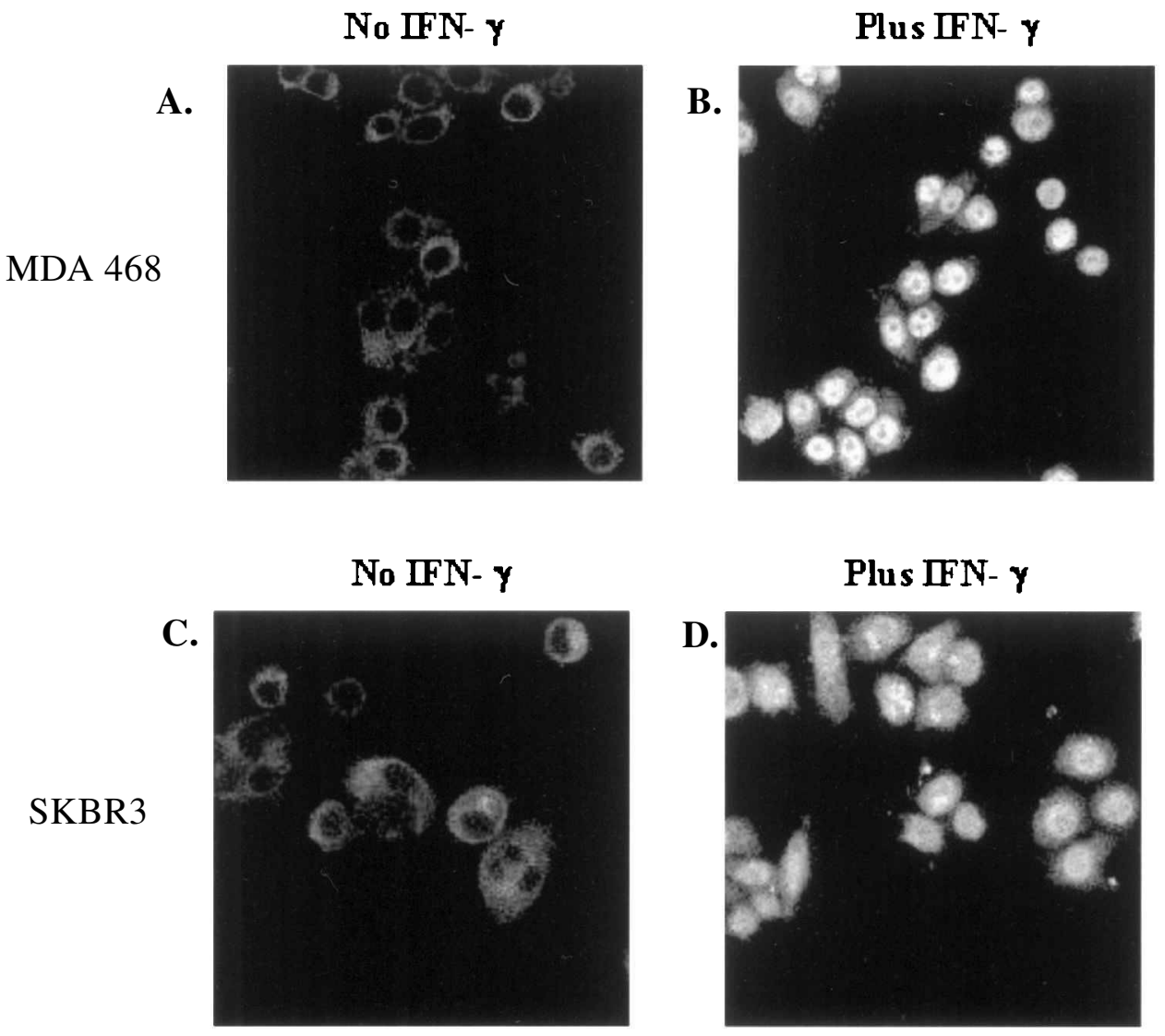

FIG. 3. IFN- $\gamma$-induced translocation of Stat-1 from the cytoplasm to the nucleus. Cells were grown overnight on chamber slides before coincubation with $100 \mathrm{U} / \mathrm{ml} \mathrm{IFN-} \gamma$ or control for $1 \mathrm{~h}$. Permeabilization was performed with $1 \%$ Triton-X 100 for 2 min. Incubation with an anti-Stat 1 primary antibody was followed by a secondary antibody conjugated to Cy3. The slides were analyzed with a confocal laser scanning microscope. (A) MDA468 without IFN- $\gamma$ exposure. (B) MDA468 after $1 \mathrm{~h}$ IFN- $\gamma$ exposure. (C) SKBR3 without IFN- $\gamma$ exposure. (D) SKBR3 after $1 \mathrm{~h}$ IFN- $\gamma$ exposure. 


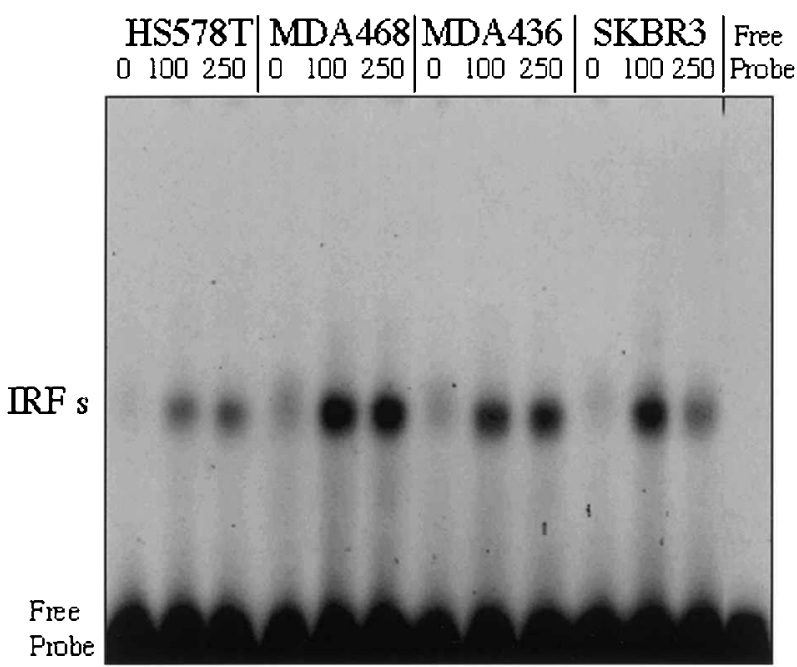

FIG. 4. IFN- $\gamma$-induced IRF expression by EMSA. Each cell line was plated at $5 \times 10^{5}$ cells/well in 6 -well plates with 0 $\mathrm{U} / \mathrm{ml}, 100 \mathrm{U} / \mathrm{ml}$, or $250 \mathrm{U} / \mathrm{ml}$ IFN- $\gamma$ for 2 days. Whole cell extracts were isolated and incubated with radiolabeled $\mathrm{C} 13$ oligomer, which binds both IRF-1 and IRF-2. The samples were then separated on nondenaturing $4 \%$ acrylamide gel and visualized by autoradiography. Cold competitive experiments using unlabeled C13 oligomer completely eliminated all bands (data not shown). Similar results were obtained after 3 days of IFN$\gamma$ incubation (data not shown). ships were confirmed in repeated experiments, using either or both IRF-1 antibody and IRF-2 antibody to distinguish the two proteins, whether comparing supershifted with unshifted complex, supershifted with supershifted complex, or unshifted with unshifted complex. MDA468 had the greatest inhibitory response to IFN- $\gamma$ and had the highest ratio of IRF-1/IRF-2. HS578T and MDA436 had an intermediate inhibitory response to IFN- $\gamma$ and had intermediate IRF-1/IRF-2 ratios. SKBR3 had almost no response to IFN- $\gamma$ and had the lowest ratio (Fig. 5). We also performed Western blots using the IRF-1 and IRF-2 antibodies in SKBR3 and MDA468, with results consistent with EMSA (data not shown), but as stated previously, there is no way to compare the ratios of IRF-1/IRF-2 using different antibodies with Western blot, as is achievable with EMSA.

To further define these marked differences in the ratios after IFN- $\gamma$ stimulation, we compared the induction of IRF-1 binding activity and IRF-2 binding activity of each cell line after incubation with IFN- $\gamma$. As shown in Figure 6, unstimulated cells showed little or no IRF-1-binding activity, but when incubated with $100 \mathrm{U} / \mathrm{ml}$ IFN- $\gamma$ for 2 days, there was a marked induction of IRF-1, correlating with the mRNA expression data by RT-PCR (Fig. 2). SKBR3 had clear induction of IRF-1, but it is the least of all the cell lines, whereas MDA468 produced the greatest IRF-1 binding activity.

IRF-2 binding activity decreased in response to IFN- $\gamma$ in the three cell lines that showed an inhibitory response to IFN- $\gamma$, and SKBR3 showed increased IRF-2 binding activity in re-
A



B

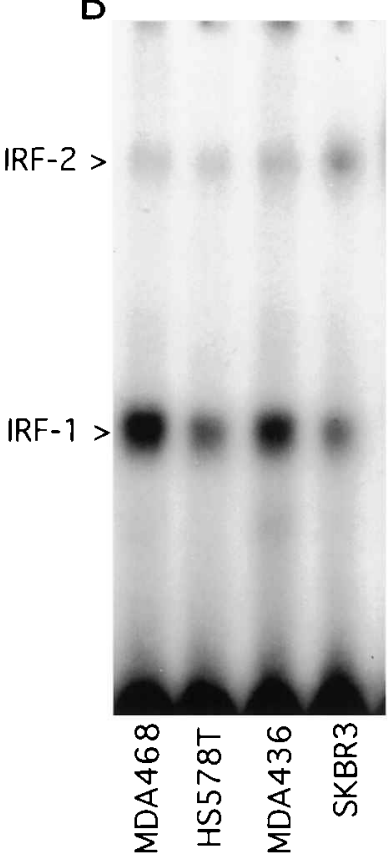

C



FIG. 5. IFN- $\gamma$ induced ratio of IRF-1/IRF-2 binding activity by EMSA. Cells were treated with $100 \mathrm{U} / \mathrm{ml}$ IFN- $\gamma$ and whole cell extract isolated as detailed in the Figure 4 legend. (A) Induced IRFs. Extract was incubated at $0^{\circ} \mathrm{C}$ for 60 min without any antibody before incubation with radiolabeled C13 oligomer. (B) Separation of IRF-1 and IRF-2 by anti-IRF-2 antibody supershift. Extract was incubated at $0^{\circ} \mathrm{C}$ for $60 \mathrm{~min}$ with anti-IRF-2 antibody before incubation with radiolabeled C13 oligomer. Samples were then run on the same nondenaturing $4 \%$ acrylamide gel and visualized by autoradiography. Anti-IRF-1 antibody demonstrated similar results (supershifted bands). (C) Densitometric ratios of IRF-1/IRF-2. Ratios of densitometric values obtained using NIH imaging software were determined from bands seen on B. Repeated experiments using either or both IRF-1 and IRF2 antibody confirmed the relationships seen in $\mathbf{B}$ and $\mathbf{C}$. 


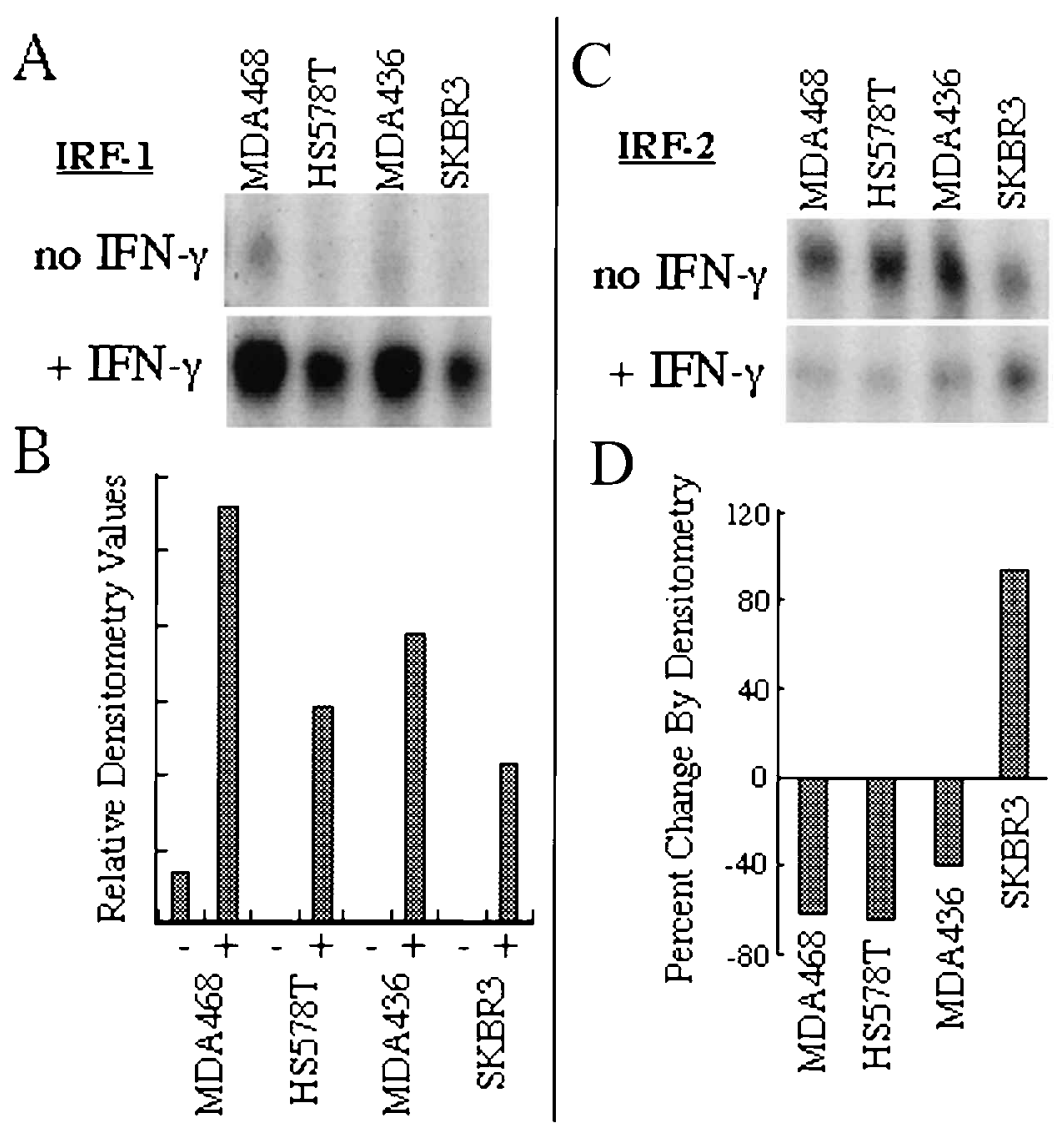

FIG. 6. IFN- $\gamma$-induced change in IRF-1 and IRF-2 binding activity by EMSA. (A) Autoradiograph comparison of samples run from cells treated with or without IFN- $\gamma$, using IRF-2 antibody with all extracts to determine IRF-1 binding activity (unsupershifted bands). Results were similar using IRF-1 antibody to determine IRF-1 binding activity (supershifted bands). (B) Densitometric comparison of IRF-1 binding activity. (C) Autoradiograph comparison of samples run from cells treated with or without IFN- $\gamma$, using IRF-2 antibody with all extracts to determine IRF-2 binding activity (supershifted bands). Results were similar using IRF-1 antibody to determine IRF-2 binding activity (unsupershifted bands). (D) Densitometric percentage change in IRF2 binding activity. All samples were treated, isolated, incubated with antibody and C13 oligomer, run on gels, and autoradiographed at the same time. Densitometric values were obtained using NIH imaging software on scanned autoradiographs.

sponse to IFN- $\gamma$ (Fig. 6). This was observed in repeated experiments whether using IRF-1 antibody, IRF-2 antibody, or both to determine the IRF-2 binding activity. This pattern contributed to the high IRF-1/IRF-2 ratio in the inhibited cell lines.

\section{Attenuation of IFN- $\gamma$ growth inhibition using IRF-I antisense oligonucleotide}

To confirm the role of IRF-1 in mediating the growth inhibitory effect of IFN- $\gamma$ we used IRF-1 AS, which has been shown to markedly decrease IRF-1 protein by immunoblotting and IRF-1 mRNA by RT-PCR. ${ }^{(30)}$ To further confirm the ability of IRF-1 AS to decrease IRF-1 in our system, we assessed IRF- 1 binding activity by EMSA of IFN- $\gamma$-treated SKBR 3 and MDA436 cells in the presence of IRF-1 AS, NS, or no oligonucleotide. There was a marked decrease in IRF-1 binding activity using IRF-1 AS, whether assessed by supershifted IRF-1 protein using IRF-1 Ab or unshifted IRF-1 protein using IRF$2 \mathrm{Ab}$, in both MDA436 (Fig. 7A) and SKBR3 (Fig. 7B). Inhibition of IRF-1 binding activity ranged from $43 \%$ to $72 \%$ vs. any control, as assessed by densitometry. When used to assess its effect on IFN- $\gamma$-mediated growth inhibition, IRF-1 AS significantly blocked the growth inhibitory effect of IFN- $\gamma$ in the MDA436 (Fig. 8A) and MDA468 (Fig. 8B) cell lines at 4-5 days in a dose-related manner. As expected, SKBR3 showed little growth inhibition by IFN- $\gamma$, which was unchanged by IRF$1 \mathrm{AS}$ at the concentrations used (Fig. 8C).

\section{DISCUSSION}

In these studies, we demonstrate that IRF-1 is directly related to the growth inhibitory activity of IFN- $\gamma$ and the IFN- $\gamma$ induced ratio of IRF-1 binding activity to IRF-2 binding activity correlates with this response in human breast carcinoma cells. This appears to be due to two factors: (1) upregulation of gene expression of IRF-1 demonstrated by increased mRNA by RT-PCR and increased IRF-1 binding activity, and (2) decreased IRF-2 binding activity in the cell lines that were growth 
No

A. Super-shifted
IRF-1

AS NS Oligo

IRF-1 Ab

\section{Unshifted IRF-1}



$\mathrm{IRF}-2 \mathrm{Ab}$

B.

\section{Super-shifted IRF-1}

IRF-1 Ab

\section{Unshifted IRF-1}

FIG. 7. Confirmation of reduction of IRF-1 binding activity by IRF-1 antisense oligonucleotide. Cells were preincubated with the indicated oligonucleotide, or no oligonucleotide, in reduced serum medium (Opti-MEM) for $4 \mathrm{~h}$, then incubated in the presence of $100 \mathrm{U} / \mathrm{ml}$ IFN- $\gamma$. Cells were harvested for EMSA after 2 days. Bands shown here are all IRF-1, and each row of bands is from the same gel and autoradiograph. IRF-1 binding activity was decreased by $43 \%$ to $72 \%$ compared with any control, as assessed by densitometry. (A) MDA436. (B) SKBR3.

inhibited and increased IRF-2 binding activity in the cell line that was not growth inhibited. These two factors produced the differences in the IRF-1/IRF-2 ratio observed in these cell lines. Furthermore, antisense oligonucleotide against IRF-1 significantly blocked the growth inhibitory effect of IFN- $\gamma$ on MDA436 and MDA468 in a dose-related manner, confirming the role of IRF-1 in mediating IFN- $\gamma$ growth inhibition in these cell lines.

There have been few studies evaluating the role of IRF-1 and IRF-2 in human tumor cell response to type I IFN and no studies before this one to assess the role of IRF-1 and IRF-2 in human tumor cell response to IFN- $\gamma$. Jelinek et al. ${ }^{(27)}$ observed a differential responsiveness to IFN- $\alpha$ in multiple myeloma cell lines, with four cell lines showing suppression of DNA synthesis by ${ }^{3} \mathrm{H}$-thymidine incorporation and one showing enhanced DNA synthesis. They found no correlation of IRF-1 or IRF-2 with this difference, and analysis of Stat1, Stat2, and Stat 3 also failed to reveal any differences. The authors also noted an increase in IRF-2 binding activity in a cell line that was responsive to IFN- $\alpha$. However, they studied IFN- $\alpha$, not IFN- $\gamma$, after only $2 \mathrm{~h}$ of stimulation, and noted that IFN- $\alpha$ was only modestly effective at inducing IRF-1 binding activity in any of their cell lines. IRF-2 binding activity dominated in the absence or presence of IFN- $\alpha$ in the growth-suppressed and growth-enhanced cell lines. Fischer et al. ${ }^{(28)}$ tried to correlate actual clinical responsiveness to IFN- $\alpha$ and IFN- $\beta$ with IRF-1 and IRF-2 expression in patients being treated for chronic myelogenous leukemia (CML) and found no correlations. However, they exclusively evaluated mRNA expression by Northern analysis. They did note that both IRF-1 and IRF-2 mRNA

were increased in mononuclear cells from CML patients both in vitro and after subcutaneous administration of IFN- $\alpha$.

We and others have found that endogenous IFN- $\gamma$ plays a substantial role in suppression of growth of tumors in syngeneic mice. In previous experiments, we have shown that a single administration of anti-IFN- $\gamma$ antibody to MCA101 and MCA105 tumor-bearing syngeneic mice caused tumor cells to grow faster when compared with nonspecific IgG-treated controls. ${ }^{(34,35)} \mathrm{We}$
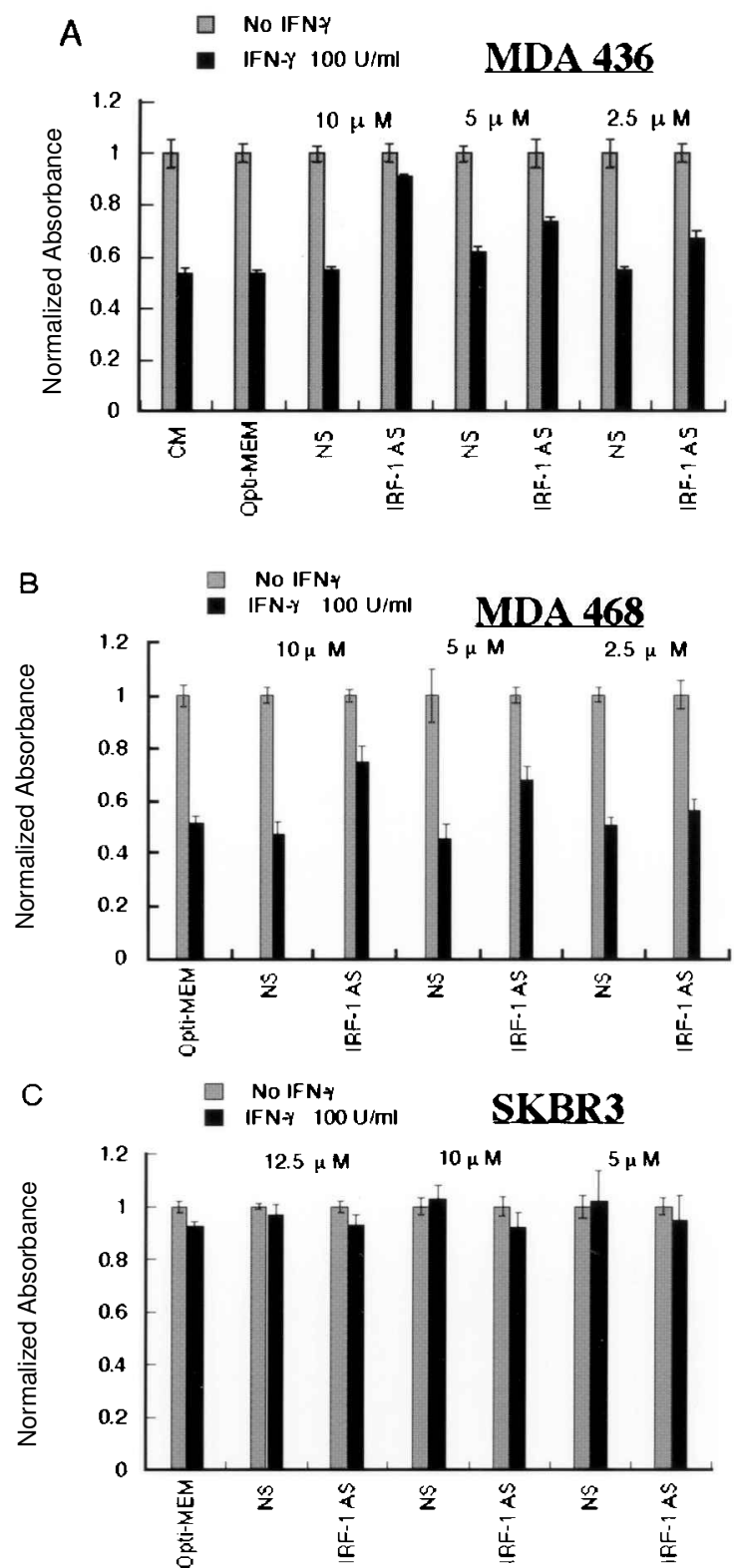

FIG. 8. IRF-1 antisense oligonucleotide attenuation of IFN$\gamma$ growth inhibition. Cells (in triplicate samples) were preincubated with the indicated oligonucleotide, or no oligonucleotide, in reduced serum medium (Opti-MEM) for $4 \mathrm{~h}$, then incubated in the presence or absence of $100 \mathrm{U} / \mathrm{ml} \mathrm{IFN}-\gamma$. MTT was used to assay viable cell number after 4-5 days. Absorbances were normalized, with unstimulated cells equal to 1 , to assist with comparison. (A) MDA436. (B) MDA468. (C) SKBR3. 
have demonstrated that B16.F10 tumors grow much more rapidly in syngeneic IFN- $\gamma$ knockout mice. ${ }^{(26)}$ Prior studies have shown that at least a major portion of the effect of endogenous IFN- $\gamma$ is directed at the tumor cells rather than host immune cells. ${ }^{(34,36)}$ These data demonstrate that in vivo tumors may be subject to a longer term, more chronic, local environment rich in IFN- $\gamma$ and that their response or lack of response to this chronic presence may play a role in the behavior of, or even the development of, malignancy. Indeed, in mice, we have shown that IRF-2 overexpression by gene transfer into B16.F10 cells causes faster tumor growth in syngeneic mice vs. untransfected and empty vector-transfected controls. This difference was almost completely abolished in IFN- $\gamma$ knockout mice, implying that resistance to chronic endogenous IFN- $\gamma$ by IRF2 expression at the level of the tumor led to this more rapid growth. ${ }^{(26)}$

There is a correlation between the induced ratio of IRF$1 /$ IRF-2 and growth inhibition by chronic IFN- $\gamma$ in human tumor cell lines, and there is a role for endogenous IFN- $\gamma$ in tumor suppression. This leads us to postulate that analysis of IRF-1 and IRF-2 expression by tumor cells in humans may correlate with tumor behavior because of resistance to endogenous IFN- $\gamma$. The aggressiveness of a tumor may depend partly on its ability to resist the tumor-suppressive effects of IFN- $\gamma$. Moreover, analysis of IRF-1 and IRF-2 expression may determine candidacy for treatment with exogenous IFN- $\gamma$ or other cytokines, including TNF- $\alpha$ and IL-12, based on the fact that IFN$\gamma$ has been found to play a role in the toxic and antitumor effects of other cytokines as well. ${ }^{(34,36,37)}$ Our initial immunohistochemical studies of archival human breast cancer specimens show a correlation between significant prognostic factors and the loss of IRF-1 expression and gain of IRF-2 expression. ${ }^{(24)}$ For human melanoma, there is a correlation between the loss of IRF-1 expression and prognosis. IRF-2 expression was not as clearly involved. Malignant melanoma thickness, stage, and histomorphology all correlate with the level of IRF1 expression, and the loss of IRF-1 expression appears to correlate with tumor progression. ${ }^{(23)}$

We did not expect to find that IRF-2 binding activity, as assessed by EMSA, decreased in three of the cell lines on incubation with IFN- $\gamma$, as previous studies have shown that IRF-2 mRNA expression is increased by IFNs and IRF-1. However, most studies evaluated IRF-2 mRNA production, not IRF-2 activity by EMSA, and the stimulating agent was more often virus or type I IFN rather than IFN- $\gamma \cdot{ }^{(17,38)}$ Finally, although increased IRF-1 binding activity has been assessed in multiple cell lines, very few cell lines have been assessed for increase in IRF-2 binding activity. In our RT-PCR experiments, we showed barely detectable IRF-2 mRNA induced by IFN- $\gamma$, usually at $24 \mathrm{~h}$, which was not detectable in unstimulated cells. However, our RT-PCR was not sufficiently sensitive to detect IRF-2 in unstimulated cells, where it was found in every cell line by EMSA. A binding sequence for IRF has been found in the promoter region of the human IRF-2 gene, and IRF-1 has been found to upregulate downstream expression at that promoter region. ${ }^{(39)}$ It may be that IFN- $\gamma$ treatment and subsequent increased IRF-1 lead to increased IRF-2 mRNA expression, and that modification occurs after transcription in the three growthinhibited cell lines, leading to decreased IRF-2 binding activity. This could include posttranscriptional or posttranslational changes or both. Finally, IRF-2 binding activity may be influenced by other factors (such as protein-proteininteractions) that prevent IRF-2 protein from binding DNA. The differential regulation of IRF-1 and IRF-2 binding activity at the transcriptional, translational, functional level despite similar proximal IFN- $\gamma$ signaling appears to be a key checkpoint for growth inhibition by IFN- $\gamma$ and will require further study.

To directly implicate the IRF-1/IRF-2 ratio in the growth inhibitory effects of IFN- $\gamma$ in these cell lines, we chose to block IRF-1 effects with antisense oligonucleotides. We used an antisense oligonucleotide (IRF-1 AS) already known to decrease IRF-1 protein by Western blot ${ }^{(30)}$ and further confirmed that this oligonucleotide can decrease IRF-1 binding activity in breast cancer cells (Fig. 7). The effects of IRF-1 AS in MDA436 and MDA468 were significant because they were sequence specific and dose dependent and caused a positive biologic effect, as demonstrated by reversal of growth inhibition in the presence of IFN- $\gamma$. We were unable to obtain an effective IRF-2 AS.

IRF-1 and IRF-2 appear to play a significant role in IFN- $\gamma$ mediated growth inhibition. Presumably this is due to upregulation of certain genes by IRF-1 and downregulation, or blockade of upregulation, of the same genes by IRF-2. Some of the genes upregulated by IRF-1 implicated in growth inhibition include the protein kinase PKR, ${ }^{(40)} 2^{\prime}, 5^{\prime}$-oligoadenylate synthetase, ${ }^{(41)}$ and lysyl oxidase. ${ }^{(42)}$ Genes with binding sequences for IRFs in their promoter region include 553 and cyclin D1, ${ }^{(41)}$ although no studies have been performed to prove that these genes are actually upregulated by IRF-1. We have preliminary evidence demonstrating that apoptosis may have a role in growth inhibition found in MDA468 because MDA468 shows markedly increased apoptosis in the presence of IFN- $\gamma$, whereas SKBR3 shows no evidence of apoptosis. Clearly, the downstream effects of IRF-1 are an area for future study.

In summary, we have found a correlation of the induced ratio of IRF-1/IRF-2 by IFN- $\gamma$ with the growth inhibitory response to IFN- $\gamma$ in vitro in four human breast carcinoma cell lines. IRF-1 mRNA and binding activity increase in correlation with growth inhibition by IFN- $\gamma$. IRF-2 binding activity actually decreases in response to IFN- $\gamma$ in inhibited cells, whereas it increases in the uninhibited cell line. IRF-1 AS attenuated IFN- $\gamma$ growth inhibition in the majority of IFN- $\gamma$ sensitive cell lines, further supporting the role of IRF-1 in IFN- $\gamma$ growth suppression. Given our understanding from previous data regarding endogenous IFN- $\gamma$ in mice, analysis of the ratio of IRF1/IRF-2 may help determine prognosis, as well as response to exogenous IFN- $\gamma$ or other cytokines, in human cancer.

\section{ACKNOWLEDGMENTS}

We thank Lisa Lammert for clerical assistance, Dr. Susan. L. DeMeester and Dr. J. Perren Cobb for help with the EMSA, Dr. Haeri Roh and Dr. Jeffrey Drebin for help with antisense oligonucleotides, and Dr. Robert D. Schreiber for fruitful discussions and a critical reading of the manuscript. This work was supported by an American Cancer Society Institutional Research grant (ACS IRG 42464), a National Cancer Institute grant R29-CA 73846-01A1, and support from the Parkview Chapter of the Barnes-Jewish Hospital Auxiliary. J.H.Y. and 
J.K.L. were supported by NIH grant 5T32 CA-09621. J.H.Y. is a recipient of an American College of Surgeons Faculty Research Fellowship.

\section{REFERENCES}

1. GELLER, D.A., NGUYEN, D., SHAPIRO, R.A., NUSSLER, A., DI SILVIO, M., FREESWICK, P., WANG, S.C., TWEARDY, D.J., SIMMONS, R.L., and BILLIAR, T.R. (1993). Cytokine induction of interferon regulatory factor-1 in hepatocytes. Surgery 114, 235-242.

2. PINE, R. (1992). Constitutive expression of an ISGF2/IRF1 transgene leads to interferon-independent activation of interferon-inducible genes and resistance to virus infection. J. Virol. 66, 4470-4478.

3. COCCIA, E.M., MARZIALI, G., STELlACCI, E., PERROTTI, E., ILARI, R., ORSATTI, R., and BATTISTINI, A. (1995). Cells resistant to interferon-beta respond to interferon-gamma via the Stat1-IRF-1 pathway. Virology 211, 113-122.

4. KAMIJO, R., HARADA, H., MATSUYAMA, T., BOSLAND, M., GERECITANO, J., SHAPIRO, D., LE, J., KOH, S. I., KIMURA, T., GREEN, S.J., MAK, T.W., TANIGUCHI, T., and VILCEK, J. (1994). Requirement for transcription factor IRF-1 in NO synthase induction in macrophages. Science 263, 1612-1615.

5. MARTIN, E., NATHAN, C., and XIE, Q.-W. (1994). Role of interferon regulatory factor 1 in induction of nitric oxide synthase. J. Exp. Med. 180, 977-984.

6. BRIKEN, V., RUFFNER, H., SCHULTZ, U., SCHWARZ, A., REIS, L.F.L., STREHLOW, I., DECKER, T., and STAEHELI, P. (1995). Interferon regulatory factor 1 is required for mouse Gbp gene activation by gamma interferon. Mol. Cell. Biol. 15, 975-982.

7. CHANG, C.-H., HAMMER, J., LOH, J.E., FODOR, W.L., and FLAVELL, R.A. (1992). The activation of major histocompatibility complex class I genes by interferon regulatory factor-1 (IRF1). Immunogenetics 35, 378-384.

8. LIM, S.P., and HUI, K.M. (1994). Characterization of a novel IRF1 deficient mutant cell line. Immunogenetics 39, 168-177.

9. REIS, L.F.L., HARADA, H., WOLCHOK, J.D., TANIGUCHI, T., and VILCEK, J. (1992). Critical role of a common transcription factor, IRF-1, in the regulation of IFN-beta and IFN-inducible genes. EMBO J. 11, 185-193.

10. HOBART, M., RAMASSAR, V., GOES, N., URMSON, J., and HALLORAN, P.F. (1997). IFN regulatory factor-1 plays a central role in the regulation of the expression of class I and II MHC genes in vivo. J. Immunol. 158, 4260-4269.

11. HOBART, M., RAMASSAR, V., GOES, N., URMSON, J., and HALLORAN, P.F. (1996). The induction of class I and II major histocompatibility complex by allogeneic stimulation is dependent on the transcription factor interferon regulatory factor 1 (IRF-1). Transplantation 62, 1895-1901.

12. YIM, J.H., WU, S.J., CASEY, M.J., NORTON, J.A., and DOHERTY, G.M. (1997). Interferon regulatory factor-1 gene transfer into an aggressive, nonimmunogenic sarcoma suppresses the malignant phenotype and enhances immunogenicity in syngeneic mice. J. Immunol. 158, 1284-1292.

13. HARADA, H., WILLISON, K., SAKAKIBARA, J., MIYAMOTO, M., FUJITA, T., and TANIGUCHI, T. (1990). Absence of the type 1 IFN system in EC cells: transcriptional activator (IRF-1) and repressor (IRF-2) genes are developmentally regulated. Cell $\mathbf{6 3}$, 303-312.

14. FUJITA, T., KIMURA, Y., MIYAMOTO, M., BARSOUMIAN, E.L., and TANIGUCHI, T. (1989). Induction of endogenous IFNalpha and IFN-beta genes by a regulatory transcription factor, IRF1. Nature 337, 270-272.
15. CHOW, W.A., FANG, J.J., and YEE, J.K. (2000). The IFN regulatory factor family participates in regulation of Fas ligand gene expression in T cells. J. Immunol. 164, 3512-3518.

16. BLANCO, J.C., CONTURSI, C., SALKOWSKI, C.A., DEWITT, D.L., OZATO, K., and VOGEL, S.N. (2000). Interferon regulatory factor (IRF)-1 and IRF-2 regulate interferon gamma-dependent cyclooxygenase 2 expression. J. Exp. Med. 191, 2131-2144.

17. WATANABE, N., SAKAKIBARA, J., HOVANESSIAN, A.G., TANIGUCHI, T., and FUJITA, T. (1991). Activation of IFN-beta element by IRF-1 requires a post-translational event in addition to IRF-1 synthesis. Nucleic Acids Res. 19, 4421-4428.

18. HARADA, H., KITAGAWA, M., TANAKA, N., YAMAMOTO, H., HARADA, K., ISHIHARA, M., and TANIGUCHI, T. (1993). Anti-oncogenic and oncogenic potentials of interferon regulatory factors-1 and -2. Science 259, 971-974.

19. TANAKA, N., ISHIHARA, M., KITAGAWA, M., HARADA, H., KIMURA, T., MATSUYAMA, T., LAMPHIER, M.S., AIZAWA, S., MAK, T.W., and TANIGUCHI, T. (1994). Cellular commitment to oncogene-induced transformation or apoptosis is dependent on the transcription factor IRF-1. Cell 77, 829-839.

20. WILLIAM, C.L., SEVER, C.E., PALLAVICINI, M.G., HARADA, H., TANAKA, N., SLOVAK, M.L., YAMAMOTO, H., HARADA, K., MEEKER, T.C., LIST, A.F., and TANIGUCHI, T. (1993). Deletion of IRF-1, mapping to chromosome 5q31.1, in human leukemia and preleukemic myelodysplasia. Science 259, 968-970.

21. TAMURA, G., OGASAWARA, S., NISHIZUKA, S., SAKATA, K., MAESAWA, C., SUZUKI, Y., TERASHIMA, M., SAITO, K. and SATODTE, R. (1996). Two distinct regions of deletion on the long arm of chromosome 5 in differentiated adenocarcinomas of the stomach. Cancer Res. 56, 612-615.

22. OGASAWARA, S., TAMURA, G., MAESAWA, C., SUZUKI, Y., ISHIDA, K., SATOH, N., UESUGI, N., SAITO, K., and SATODATE, R. (1996). Common deleted region on the long arm of chromosome 5 in esophageal carcinoma. Gastroenterology 110, 52-57.

23. LOWNEY, J.K., BOUCHER, L.D., SWANSON, P.E., and DOHERTY, G.M. (1999). Interferon regulatory factor-1 and -2 expression in human melanoma specimens. Ann. Surg. Oncol. 6, 604-608.

24. DOHERTY, G.M., BOUCHER, L., SORENSON, K., and LOWNEY, J. (2001). Interferon regulatory factor expression in human breast cancer. Ann. Surg. 233, 623-629.

25. DOHERTY, G.M., McCLUSKEY, B., TSUNG, K., and NORTON, J.A. (1995). Correlation of interferon regulatory factors 1 and 2 (IRF-1 and -2): expression and murine tumor growth in the presence of interferon-gamma. Surg. Forum 46, 544-546.

26. YIM, J.H., WU, S.J., LOWNEY, J.K., VANDER VELDE, T.L., and DOHERTY, G.M. (1999). Enhancing in vivo tumorigenicity of B16 melanoma by overexpressing interferon regulatory factor2: resistance to endogenous IFN- $\gamma$. J Interferon Cytokine Res. 19, 723-729.

27. JELINEK, D.F., AAGAARD-TILLERY, K.M., ARENDT, B.K., ARORA, T., TSCHUMPER, R.C., and WESTENDORF, J.J. (1997). Differential human multiple myeloma cell line responsiveness to interferon-alpha. Analysis of transcription factor activation and interleukin 6 receptor expression. J. Clin. Invest. 99, 447-456.

28. FISCHER, T., AMAN, J., VAN DER KUIP, H., RUDOLF, G., PESCHEL, C., AULITZKY, W.E., and HUBER, C. (1996). Induction of interferon regulatory factors $2^{\prime}-5^{\prime}$ oligoadenylate synthetase, p68 kinase and RNase L in chronic myelogenous leukaemia cells and its relationship to clinical responsiveness. Br. J. Haematol. 92, 595-603.

29. FUJITA, T., SHIBUYA, H., HOTTA, H., YAMANISHI, K., and TANIGUCHI, T. (1987). Interferon-beta gene regulation: tandemly repeated sequences of a synthetic 6 bp oligomer function as a virusinducible enhancer. Cell 49, 357-367. 
30. SATO, T., SELLERI, C., YOUNG, N.S., and MACIEJEWSKI, J.P. (1995). Hematopoietic inhibition by interferon-gamma is partially mediated through interferon regulatory factor- 1 . Blood $\mathbf{8 6}$, 3373-3380.

31. DARNELL, J.E. (1997). Stats and gene regulation. Science 277, 1630-1637.

32. SHUAI, K., STARK, G.R., KERR, I.M., and DARNELL, J.E. (1993). A single phosphotyrosine residue of Stat91 required for gene activation by interferon- $\gamma$. Science 261, 1744-1746.

33. WONG, L.H., KRAUER, K.G., HATZINISIRIOU, I., ESTCOURT, M.J., HERSEY, P., TAM, N.D., EDMONDSON, S., DEVENISH, R.J., and RALPH, S.J. (1997). Interferon-resistant human melanoma cells are deficient in ISGF3 components, Stat1, Stat2, and p48-ISGF3 $\gamma$. J. Biol. Chem. 272, 2877928785.

34. DOHERTY, G.M., TSUNG, K., McCLUSKEY, B., and NORTON, J.A. (1996). Endogenous interferon-gamma acts directly on tumor cells in vivo to suppress growth. J. Surg. Res. 64, 68-74.

35. DOHERTY, G.M., ALEXANDER, H.R., MERINO, M.J., VENZON, D.J., and NORTON, J.A. (1996). Role of endogenous interferon gamma in murine tumor growth and tumor necrosis factor alpha antitumor efficacy. Ann. Surg. Oncol. 3, 198-203.

36. DOHERTY, G.M., LANGE, J.R., LANGSTEIN, H.N., ALEXANDER, H.R., BIRESH, C.M., and NORTON, J.A. (1992). Evidence for IFN-gamma as a mediator of the lethality of endotoxin and tumor necrosis factor-alpha. J. Immunol. 149, 1666-1670.

37. NASTALA, C.L., EDINGTON, H.D., McKINNEY, T.G., TAHARA, H., NALESNIK, M.A., BRUNDA, M.J., GATELY, M.K., WOLF, S.F., SCHREIBER, R.D., STORKUS, W.J., and LOTZE, M.T. (1994). Recombinant IL-12 administration induces tumor regression in association with IFN-gamma production. J. Immunol. 153, 1697-1706.
38. HARADA, H., FUJITA, T., MIYAMOTO, M., KIMURA, Y., MURAYAMA, M., FURIA, A., MIYATA, T., and TANIGUCHI, T. (1989). Structurally similar but functionally distinct factors, IRF1 and IRF-2, bind to the same regulatory elements of IFN and IFNinducible genes. Cell 58, 729-739.

39. CHA, Y. and DEISSEROTH, A.B. (1994). Human interferon regulartory factor 2 gene. J. Biol. Chem. 269, 5279-5287.

40. KIRCHHOFF, S., KOROMILAS, A.E., SCHAPER, F., GRASHOFF, M., SONENBERG, N., and HAUSER, H. (1995). IRF-1 induced cell growth inhibition and interferon induction requires the activity of the protein kinase PKR. Oncogene 11, 439-445.

41. TANAKA, N., KAWAKAMI, T., and TANIGUCHI, T. (1993). Recognition DNA sequences of interferon regulatory factor 1 (IRF1) and IRF-2, regulators of cell growth and the interferon system. Mol. Cell. Biol. 13, 4531-4538.

42. SOK-PIN TAN, R., TANIGUCHI, T., and HARADA, H. (1996). Identification of the lysyl oxidase gene as a target of the antioncogenic transcription factor, IRF-1, and its possible role in tu-

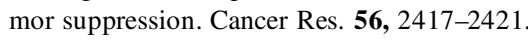

Address reprint requests or correspondence to: Dr. Gerard M. Doherty 2920 Taubman Center University of Michigan 1500 E. Medical Center Drive Ann Arbor, MI 48109

Tel: (734) 615-4741

Fax: (734) 936-5830

E-mail: gerardd@umich.edu

Received 21 January 2003/Accepted 28 May 2003 


\section{This article has been cited by:}

1. Tomohiko Tamura, Hideyuki Yanai, David Savitsky, Tadatsugu Taniguchi. 2008. The IRF Family Transcription Factors in Immunity and Oncogenesis. Annual Review of Immunology 26:1, 535-584. [CrossRef]

2. M T Stang, M J Armstrong, G A Watson, K Y Sung, Y Liu, B Ren, J H Yim. 2007. Interferon regulatory factor-1-induced apoptosis mediated by a ligand-independent fas-associated death domain pathway in breast cancer cells. Oncogene 26:44, 6420-6430. [CrossRef]

3. Judith M. Connett, Linda Badri , Thomas J. Giordano, William C. Connett, Dr. Gerard M. Doherty . 2005. Interferon Regulatory Factor 1 (IRF-1) and IRF-2 Expression in Breast Cancer Tissue MicroarraysInterferon Regulatory Factor 1 (IRF-1) and IRF-2 Expression in Breast Cancer Tissue Microarrays. Journal of Interferon Cytokine Research 25:10, 587-594. [Abstract] [PDF] [PDF Plus] 